\title{
Daily bacterioplankton dynamics in a sub-Saharan estuary (Senegal River, West Africa): a mesocosm study
}

\author{
Marc Troussellier ${ }^{1}$, Patrice Got ${ }^{1}$, Maimouna Mboup ${ }^{2}$, Daniel Corbin ${ }^{2}$, \\ Laura Giuliano ${ }^{3}$, Simone Cappello ${ }^{3}$, Marc Bouvy ${ }^{1,2, *}$ \\ ${ }^{1}$ Laboratoire Ecosystèmes Lagunaires UMR-CNRS 5119, Equipe EMMA, Université Montpellier II, 34095 Montpellier, France \\ ${ }^{2}$ Centre IRD Bel Air, BP 1386, UR 098 Dakar, Senegal \\ ${ }^{3}$ Istituto Sperimentale Talassografico - Consiglio Nazionale delle Ricerche, Spianata San Raineri 84, 98122 Messina, Italy
}

\begin{abstract}
Temporal variability in bacterial communities was studied on a daily scale in the estuarine part of the largest river on the West African coast, the Senegal River. Duplicate mesocosms $\left(3 \mathrm{~m}^{3}\right.$ volume) were placed in the upper part of the estuary at the end of the dry season (May 2002) and treated with low and high inorganic nutrient ( $\mathrm{N}$ and $\mathrm{P}$ ) enrichment. High nutrient additions were followed by a 7 -fold increase in phytoplankton biomass and a 6 -fold increase in bacterial abundance after 4 and $9 \mathrm{~d}$, respectively. Heterotrophic nanoflagellates (HNF) showed their maximal abundance $\left(1 \times 10^{6} \mathrm{ml}^{-1}\right) 2 \mathrm{~d}$ after the bacterial peak. The low bacteria to flagellate ratios recorded on Day 10 may suggest enhanced bacterivory from HNF. Simultaneous measurements of growth and grazing rates on bacteria during the bacterial growth phase were performed with the dilution method and seemed to indicate that the HNF community was capable of quickly controlling bacterial development. However, estimates of the carbon demand of HNF during their growth phase $\left(915 \mu \mathrm{g} \mathrm{C}^{-1} \mathrm{~d}^{-1}\right)$ appeared to be more elevated than the bacterial carbon production ( $63 \%$ of the HNF carbon demand). To cover HNF carbon requirements, an alternative/complementary prey might be the picophytoplanktonic cells, which were very numerous during the study (i.e. $85 \%$ of the total phytoplankton count). During the period of high grazing pressure, bacterial populations were characterized by higher specific activity (from tritiated thymidine incorporation) and culturability (from plate counts). The presence of very large bacteria, as detected by epifluorescence microscopy and flow cytometry measurements, may be an escape response from flagellate grazing. 16S rDNA sequences from bacterial isolates showed the presence of 2 types of taxonomic units (Vibrio natriegens- and Flexibacter maritimus-like bacteria), which can be considered by their forms and growth rates to be strains that have developed strategies to protect against grazing. Thus, as demonstrated in various temperate systems, predation by HNF in estuarine tropical ecosystems may also be of importance in shaping the structure and functions of the bacterial community.
\end{abstract}

KEY WORDS: Bacteria · Heterotrophic nanoflagellates · Mesocosms $\cdot$ Growth and grazing rates · Senegal estuary · West Africa

\section{INTRODUCTION}

Due to their multiple roles in the functioning of aquatic ecosystems (Azam et al. 1983, Kirchman 2000), bacterial abundance and activities have been extensively studied during the past years (Laybourn-Parry \& Parry 2000, Jurgens \& Matz 2002, Sherr \& Sherr 2002).
Among aquatic ecosystems, coastal areas, and especially estuaries, have received a great deal of attention, because they often provide very important ecological, recreational and economic resources (Costanza et al. 1997). Because of the increasing density of inhabitants in coastal areas (Scialabba 1998), nutrient enrichment leads to the eutrophication of a large number of these 
zones (e.g. Cloern 2001). One consequence of eutrophication is the increase in primary production and, therefore, in fish or shellfish production in a large number of estuarine areas (Nixon 1988, Albaret \& Laë 2003). Another consequence of eutrophication is that bacterial standing stocks and production are high in estuaries when compared to other marine ecosystems (Ducklow \& Carlson 1992, Ducklow \& Shiah 1993). While mainly dedicated to temperate coastal areas, the literature showed that the highest values of bacterial abundance and production have been recorded in tropical areas (Torréton et al. 1989, Arfi et al. 2002, Murrel 2003, Troussellier et al. 2004). Nevertheless, among tropical areas, African coastal and estuarine waters have received little attention in connection with both resources and increasing anthropic pressures.

The Senegal River is the larger river on the NW coast of Africa. The Senegal River watershed covers nearly $335000 \mathrm{~km}^{2}$ and spreads over 4 countries (Guinea, Mali, Mauritania, Senegal). Despite its huge importance as a water resource for human, animal and agricultural needs, as well as for fisheries, only 1 recent study has been dedicated to an estimation of the trophic status of the Senegal River (Troussellier et al. 2004). Although inorganic nutrient concentrations were low, microbiological variables exhibited high values characterizing eutrophicated coastal waters (Troussellier et al. 2004).

Information on the timescales of the variability of bacterial development is rather scarce, especially for shallow estuaries, which are very dynamic environments, subject to frequent drastic changes in hydrodynamic conditions on a timescale of days (Iriarte et al. 2003). One central question in aquatic microbial ecology involves the relative importance of resource limitation, grazing and viral mortality on both the functional and taxonomic diversity of bacterial communities (Jürgens et al. 1999, Jürgens \& Matz 2002). In coastal eutrophic areas, the nature and availability of inorganic and organic nutrients may play important roles in the structure of bacterial communities. On the other hand, ample evidence exists that heterotrophic protists are generally the main grazers of bacterial biomass, in both oligotrophic and eutrophic waters (Vaqué et al. 1992, Storm 2000). Nevertheless, many small and medium flagellates also have the potential to graze on autotrophic picoplankton (Kuosa 1990). Studies that simultaneously measure changes in growth, phylogenetic composition and in the morphological properties of the bacterial community are just beginning to be done. To elucidate these modifications, it may, therefore, be necessary to perform experiments in which the main control factors are studied. One of the main advantages of a mesocosm study is that mechanistic information on ecological processes can be acquired by changing environmental conditions that would alter unpredictably in a field study (Shiah \& Ducklow 1995). By using in situ floating mesocosms, the present study was performed to examine, on a daily scale, the temporal variability of bacterioplankton and its bottom-up (nutrient enrichment) and top-down (grazing by heterotrophic flagellates) controlling factors.

\section{MATERIALS AND METHODS}

Experimental design. The study was conducted in the Senegal River estuary, in the south of Saint Louis City at a fixed station named 'Port des Polonais' from 16 to 30 May 2002 (Fig. 1). This period, at the end of the dry season, is characterized by stable environmental conditions due to limited freshwater water inputs; the salinity of the sampled area was close to $28 \mathrm{psu}$, and the mean water temperature was $24.2^{\circ} \mathrm{C}$ (range: 22.3 to $\left.26.1^{\circ} \mathrm{C}\right)$. Therefore, the Diama dam, located $27 \mathrm{~km}$ upstream of Saint Louis City, was designed to prevent the intrusion of saline water from the Atlantic Ocean and to control the flow of the Senegal River during flooding. The 4 mesocosms (polyethylene bags, $1.5 \mathrm{~m}$ diameter $\times 2 \mathrm{~m}$ depth, $3 \mathrm{~m}^{3}$ volume) were randomly filled with estuarine water. Low nitrogen $\left(1 \mu \mathrm{mol} \mathrm{l}^{-1}\right.$ of a mixture of $\mathrm{NaNO}_{3} / \mathrm{NH}_{4} \mathrm{Cl} ; 50 \%: 50 \%$ ) and phosphorous $\left(0.1 \mu \mathrm{mol} \mathrm{l} \mathrm{l}^{-1}\right.$ of $\left.\mathrm{KH}_{2} \mathrm{PO}_{4}\right)$ concentrations were added to the control mesocosms (designated 0 ) to avoid a decline of phytoplanktonic populations. Higher $\mathrm{N}\left(20 \mu \mathrm{mol} \mathrm{l^{-1 }}\right)$ and $\mathrm{P}\left(2 \mu \mathrm{mol} \mathrm{l^{-1 }}\right)$ concentrations with the same products were added to the nutrient treatment mesocosms (designated N) to stimulate the activity of microbial populations. Same concentrations of nutrients (see above) were added every $2 \mathrm{~d}$. Water samples were taken daily using a $2 \mathrm{~m}$ sampling tube (3 $\mathrm{cm}$ diameter) that allowed the collection a depthintegrated sample in each mesocosm. They were processed within $1 \mathrm{~h}$ after collection, in field laboratories located near the mesocosm location.

Nutrient analyses. Samples for dissolved inorganic nutrient determinations $\left(\mathrm{NO}_{3}-\mathrm{N}, \mathrm{NH}_{4}-\mathrm{N}, \mathrm{PO}_{4}-\mathrm{P}\right)$ were previously filtered onto Whatman GF/F fiberglass filters, stored at $-20^{\circ} \mathrm{C}$ and analyzed according to Strickland \& Parsons (1972).

Heterotrophic nanoflagellate counts. Subsamples for determination of heterotrophic nanoflagellates (HNF) were fixed with $2 \%$ formalin (passed through $0.2 \mu \mathrm{m}$ pore-size filters) and enumerated from $4 \mathrm{ml}$ subsamples passed through black polycarbonate membrane filters $(0.8 \mu \mathrm{m}$ pore size, $25 \mathrm{~mm}$, Nuclepore). The flagellates were stained using DAPI fluorochrome (final concentration: $20 \mathrm{\mu g}^{-1}$ ) for $15 \mathrm{~min}$ and counted by epifluorescence microscopy (Olympus BX 60 microscope; magnification $1200 \times$ ). Mean flagellate 


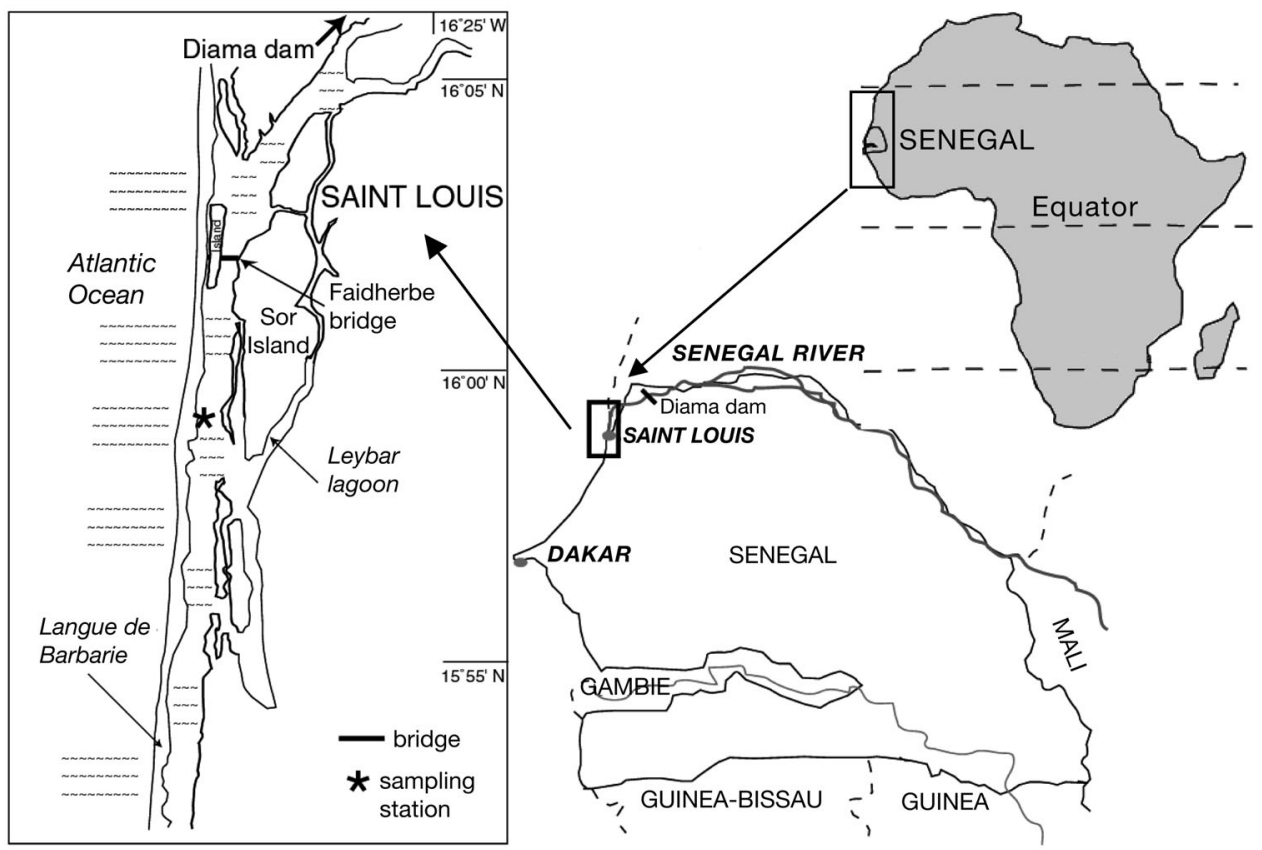

Fig. 1. The Senegal River and the location of experiments in the estuarine part of the river

volumes were determined by measurement of cells using an Olympus DP 50 camera mounted on the microscope equipped with a Plan Neofluar $100 \times / 1.3$ oil immersion objective. Images were acquired from a camera (ANALYSYS software, Soft Imaging System) housed in a computer. Cell volumes were estimated by the equation of an ellipsoid.

Autotrophic flagellates were discriminated from heterotrophs by the red autofluorescence of chlorophyll a observed under blue-light excitation. Data presented in this paper only apply to heterotrophic protozoans.

Bacterial community characteristics. Subsamples for determination of bacterial abundances were fixed with sterile formalin ( $2 \%$ final concentration, passed through a $0.2 \mu \mathrm{m}$ pore-size filter), stained with DAPI fluorochrome (Porter \& Feig 1980), passed through black polycarbonate membrane filters $(0.2 \mu \mathrm{m}$ pore size, $25 \mathrm{~mm}$, Nuclepore) and counted with an Olympus BX 60 epifluorescence microscope. Bacteria were measured using an Olympus DP50 camera (see above) and were computed using the formula described by Blackburn et al. (1998).

Bacterial activity was estimated through (methyl- ${ }^{3} \mathrm{H}$ ) thymidine incorporation into cold trichloroacetic acid (TCA) precipitate (Fuhrman \& Azam 1980). Duplicates and 1 control (zero time) were incubated with (methyl${ }^{3} \mathrm{H}$ )-thymidine (47 $\mathrm{Ci} \mathrm{mmol}^{-1}$, Amersham) in the dark at in situ temperature. The incubation time was $15 \mathrm{~min}$, with a final thymidine concentration of $20 \mathrm{nM}$, assum- ing that isotope dilution can be prevented at this concentration (Robarts \& Zohary 1993). Radioactivity was counted by the liquid scintillation procedure, and results are expressed as nanomoles of incorporated thymidine per liter and per hour.

Flow cytometry analyses of the bacterial community were performed on the basis of SYBR-Green I (Molecular Probes) staining of bacterial cells following the method described by Marie et al. (1997). Subsamples were fixed with buffered formalin and immediately stored in liquid nitrogen until analysis. For each subsample, 3 replicate counts were performed with a FACSCalibur flow cytometer (Becton Dickinson) equipped with an air-cooled argon laser (488 nm, $15 \mathrm{~mW}$ ). Stained bacterial cells, excited at $488 \mathrm{~nm}$, were enumerated according to their right-angle light scatter (RALS) and green fluorescence (FL1) collected at 530/30 nm. Fluorescent beads $(0.94 \mu \mathrm{m}$, Polysciences) were systematically added to each sample. Different bacterial cell populations can be discriminated by variations in their increasing fluorescence intensity (FL1) and their increasing scatter values (SSC). Apparent biomass of these different cell populations was estimated following Troussellier et al. (1999).

Culturable heterotrophic bacterial counts were performed for all mesocosms by plating $100 \mu \mathrm{l}$ of raw water or of decimal dilutions onto Marine Agar plates (Difco medium). Primary isolates were obtained from Marine Agar (Difco) spread-plate cultures of water samples collected during the growth phase (T5) of the 
bacterial community in enriched mesocosms (N). Then, isolates were purified by subsequent passage to Marine Agar plates, and, when pure clones were obtained, they were preserved both in Marine Agar tubes and in liquid nitrogen $\left(-196^{\circ} \mathrm{C}\right)$. Ten random clones were selected for further genetic characterization.

Total DNA extraction of bacterial strains with the DNA/RNA Extraction Mini Kit (QIAGEN) was performed according to the manufacture's protocol. The 16S rDNA loci were amplified using 1 primer pair: the 16F27 (5'-AGAGTTTGATCCTGGCTCAG-3') primer and the 16R1492 (5'-TACGGYTACCTTGTTACGACT$\left.3^{\prime}\right)$ universal primer. PCR (polymerase chain reaction) was carried out in $50 \mu \mathrm{l}$ of reaction mixture containing $1 \times$ reaction buffer, $1 \times$ solution $Q$ (both from QIAGEN), $1 \mu \mathrm{M}$ of each primer, $200 \mu \mathrm{M}$ dNTP (Gibco), $1 \mu \mathrm{l}$ of template and 2.5 U of Qiagen Taq polymerase. The PCR reaction was realized in Mastercycler Gradient (Eppendorf); the PCR conditions were as follows: $95^{\circ} \mathrm{C}$ for $5 \mathrm{~min}(1 \mathrm{cycle}) ; 94^{\circ} \mathrm{C}$ for $1 \mathrm{~min}, 50^{\circ} \mathrm{C}$ for $1 \mathrm{~min}$ and $72^{\circ} \mathrm{C}$ for 2 min (35 cycles); with a final extension step at $72^{\circ} \mathrm{C}$ for $10 \mathrm{~min}$. The $16 \mathrm{~S}$ rDNA amplified was sequenced using a ABI 3100 Avant Genetic Analyser (Applied Biosystems-Hitachi) with the reaction kit (PE) of the ABI Prism Big Dye Ver. 3.1 Terminator Cycle Sequencer. To estimate the degree of similarity to other 16S rRNA, gene analysis of the obtained sequences was performed using SIMILARITY_MATRIX, SEQUENCE_MATCH and SEQUENCE_ALIGN from the Ribosomal Database Project II.

Phytoplankton analyses. Water samples for chlorophyll $a$ analysis were passed through Whatman GF/F filters and stored in liquid nitrogen. Chlorophyll a concentrations were determined fluorometrically after methanol extraction (Yentsch \& Menzel 1963). Phytoplankton counts were performed with the same flow cytometer as the one used for bacteria (see above), following Troussellier et al. (2004). Fluorescent beads (0.94 $\mu \mathrm{m}$ and $2 \mu \mathrm{m}$ ) (Polysciences) were systematically added to each sample. Different phytoplanktonic groups were discriminated according to their fluorescence and scatter characteristics as previously described (Troussellier et al. 1993). Only 2 phytoplanktonic groups have been considered in this study: picophytoplanktonic and nanophytoplanktonic cells.

Bacterial growth and bacterivory. The bacterial community growth $(\mu)$ and grazing $(g)$ rates by HNF were estimated using the dilution technique of Landry \& Hassett (1982). Three experiments were conducted during the survey (T1, T3 and T8). From each mesocosm ( $\mathrm{N}$ and 0 , in duplicate), subsamples of freshly collected water samples were pre-filtered through $60 \mu \mathrm{m}$-meshed gauze to exclude zooplankton. Using $0.22 \mu \mathrm{m}$ filtered water from mesocoms, different dilutions were then performed. The ratios of original to filtered samples were: 100:0, 75:25, 50:50 and 25:75. Dilution series were incubated ( $24 \mathrm{~h})$ in the mesocosms from which the water was collected.

Ingestion ( $I$, bact. $\mathrm{HNF}^{-1} \mathrm{~h}^{-1}$ ) and clearance $(C, \mathrm{nl}$ $\mathrm{HNF}^{-1} \mathrm{~h}^{-1}$ ) rates of HNF were calculated according to Davies \& Sieburth (1984):

$$
I=g \times N_{\mathrm{bact}} / N_{\mathrm{HNF}}
$$

where $g$ is the grazing rate $\left(\mathrm{h}^{-1}\right)$ and $N_{\text {bact }}$ and $N_{\mathrm{HNF}}$ are the average concentrations of bacteria and HNF, respectively; and:

$$
C=I / N_{\text {bact }}
$$

\section{RESULTS}

\section{Initial environmental conditions and microbial community structure}

During the sampling period, the flow of the river was close to zero due to the retention of freshwater by the Diama dam. The initial values of nutrient concentrations appeared to be very low $\left(\mathrm{NH}_{4}=0.60 \mu \mathrm{mol} \mathrm{l^{-1 }}\right.$, $\mathrm{NO}_{3}=0.20 \mu \mathrm{mol} \mathrm{l}{ }^{-1}$ and $\mathrm{PO}_{4}=0.30 \mu \mathrm{mol} \mathrm{l}{ }^{-1}$ ), while the mean value of chlorophyll a $\left(9.6 \mu \mathrm{g}^{-1}\right)$ was relatively high during this period of the dry season (M. Bouvy pers. comm.). The mean abundances of the different types of microorganisms we measured at the beginning of the experiments are reported in Table 1. Total phytoplanktonic abundance as estimated by flow cytometry was $1.34 \times 10^{5}$ cells $\mathrm{ml}^{-1}$. Among the phytoplanktonic assemblage, picophytoplanktonic cells represented nearly $85 \%$ of the total count. Total bacterial abundances rose to a mean of $4.35 \times 10^{6}$ cells ml $^{-1}$, with incorporation rates of ${ }^{3} \mathrm{H}$-thymidine close to $0.05 \mathrm{nmol}$ $\mathrm{l}^{-1} \mathrm{~h}^{-1}$. HNF were also very abundant, with a mean of $1.92 \times 10^{4}$ cells $\mathrm{ml}^{-1}$.

\section{Responses of the microbial community to treatments}

The responses of the microbial community were statistically similar for the duplicates, with coefficients of variation generally $<37 \%$, independent of the variables studied. Generally the highest coefficients were observed at the end of the experiment (after $10 \mathrm{~d}$ ).

\section{Phytoplankton biomass and nutrients}

When inorganic nutrients were added $(\mathrm{N})$, there was initially a large increase in phytoplanktonic biomass (Fig. 2) during the first $5 \mathrm{~d}$, with values of chlorophyll $a$ rising to $70 \mu \mathrm{g} \mathrm{l}^{-1}$. In the control mesocosms $(0)$, there 
Table 1. Estuarine water and microbial community characteristics at the beginning of the mesocosm experiments. Mean and standard deviation values were computed from the initial values (T0) of the different variables measured in the 4 mesocosms $(\mathrm{n}=4)(\mathrm{HNF}$, heterotrophic nanoflagellate $)$

\begin{tabular}{|c|c|c|}
\hline Variable & Mean & SD \\
\hline $\mathrm{N}-\mathrm{NH}_{4}\left(\mu \mathrm{mol} \mathrm{l}{ }^{-1}\right)$ & 0.6 & 0.3 \\
\hline $\mathrm{N}-\mathrm{NO}_{3}\left(\mu \mathrm{mol} \mathrm{l} \mathrm{l}^{-1}\right)$ & 0.2 & 0.3 \\
\hline $\mathrm{P}_{-} \mathrm{PO}_{4}\left(\mu \mathrm{mol} \mathrm{l}{ }^{-1}\right)$ & 0.3 & 0.3 \\
\hline Chlorophyll a $\left(\mu \mathrm{g} \mathrm{l}^{-1}\right)$ & 9.6 & 0.8 \\
\hline $\begin{array}{l}\text { Total phytoplanktonic } \\
\text { abundance (cells } \mathrm{ml}^{-1} \text { ) }\end{array}$ & $1.34 \times 10^{5}$ & $1.19 \times 10^{4}$ \\
\hline $\begin{array}{l}\text { Picophytoplanktonic } \\
\text { abundance }\left(\text { cells ml }^{-1}\right)\end{array}$ & $7.75 \times 10^{4}$ & $5.89 \times 10^{3}$ \\
\hline HNF abundance (cells $\mathrm{ml}^{-1}$ ) & $5,76 \times 10^{4}$ & $8.17 \times 10^{3}$ \\
\hline $\begin{array}{l}\text { Total bacterial abundance } \\
\left(\text { cells } \mathrm{ml}^{-1}\right)\end{array}$ & $4.35 \times 10^{6}$ & $8.80 \times 10^{5}$ \\
\hline $\begin{array}{l}\text { Culturable bacterial } \\
\text { abundance (cells ml }{ }^{-1} \text { ) }\end{array}$ & $9.55 \times 10^{3}$ & $9.50 \times 10^{2}$ \\
\hline $\begin{array}{l}\text { Proportion of culturable } \\
\text { bacterial cells (\%) }\end{array}$ & 0.23 & 0.03 \\
\hline $\begin{array}{l}{ }^{3} \mathrm{H} \text {-Thy incorporation rate } \\
\left(\mathrm{nmol} \mathrm{l}^{-1} \mathrm{~h}^{-1}\right)\end{array}$ & 0.046 & 0.026 \\
\hline $\begin{array}{l}{ }^{3} \mathrm{H} \text {-Thy incorporation per } \\
\text { bacterial cell }\left(10^{-20} \mathrm{~mol} \mathrm{cell}^{-1} \mathrm{~h}^{-1}\right)\end{array}$ & 1.02 & 0.54 \\
\hline
\end{tabular}

were no significant changes during the course of the experiment.

Total and picophytoplankton abundances exhibited no significant changes in the control mesocosms, while they showed higher values in the enriched mesocosms (Table 2). On Days 2 and 4 of experiments, the increase in the enriched mesocosm was higher for total abundances than for picophytoplankton cells, suggesting that the initial increase in chlorophyll a values was linked to an increase in nanophytoplankton cells. Compared to the beginning of the experiment, where they formed nearly $58 \%$ of the total abundance, the proportion of picophytoplanktonic cells remained close

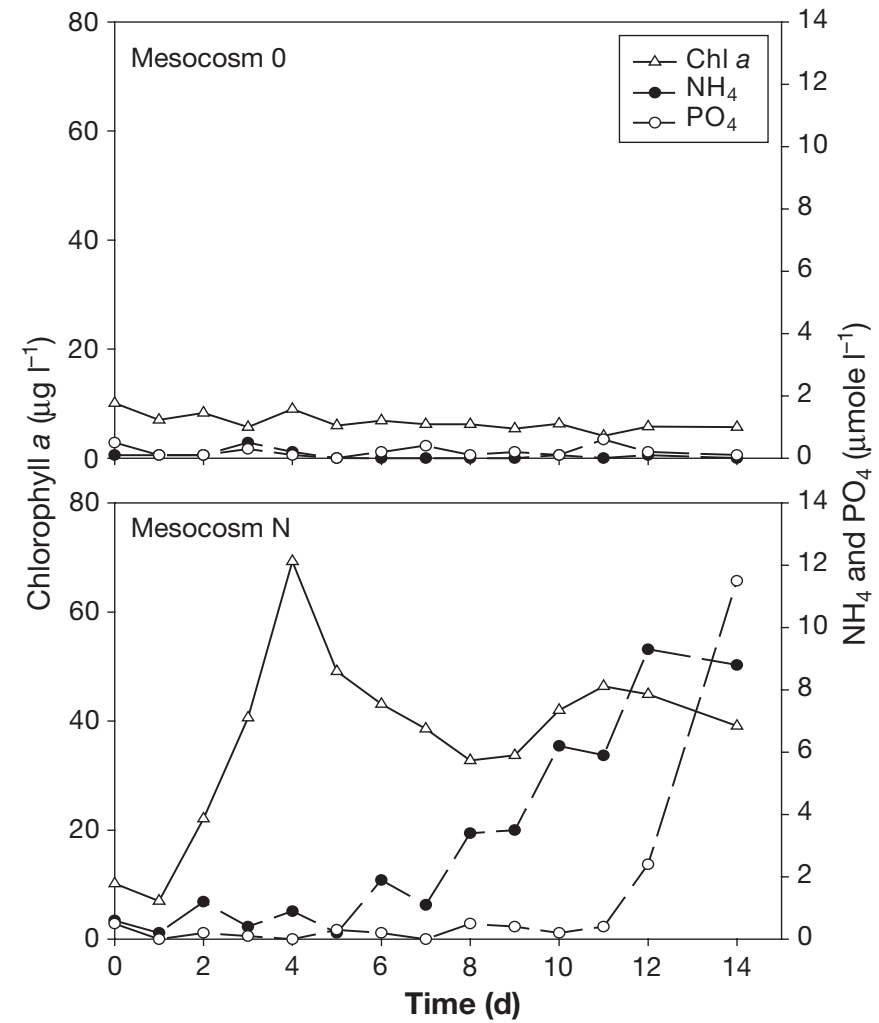

Fig. 2. Changes in mean values of nutrients $\left(\mathrm{NH}_{4}\right.$ and $\left.\mathrm{PO}_{4}\right)$ and chlorophyll a concentration in the control (0) and enriched (N) mesocosms

to this value in the control mesocosm, while it showed a slight decrease in the enriched mesocosm (44 to $39 \%$ ).

Nutrient concentrations remained higher in enriched mesocosms $(\mathrm{N})$, where they were added in a continuous way and showed an increase once the phytoplankton bloom decreased (Fig. 2). Nitrate concentrations fluctuated for both treatments, similar to those described for ammonium concentrations, with the highest values recorded at the end of the experiment (close to $20 \mu \mathrm{mol} \mathrm{l}{ }^{-1}$, data not shown).

Table 2. Phytoplankton (total and picophytoplankton), bacterial and heterotrophic nanoflagellate (HNF) abundances in the mesocosms at different times (T2, T4 and T9) of dilution experiments, in control (0) and enriched (N) mesocosms. At each time for both mesocosms, bacterial growth $(\mu)$ and grazing $(g)$ rates of bacterial community were estimated by the dilution method; ingestion rates $(I)$ and filtration rates $(C)$ were calculated from bacterial and HNF abundances

\begin{tabular}{|c|c|c|c|c|c|c|c|c|}
\hline $\begin{array}{l}\text { Time } \\
\text { (treatment) }\end{array}$ & $\begin{array}{c}\text { Total } \\
\text { phytoplankton } \\
\text { (cell } \mathrm{ml}^{-1} \text { ) }\end{array}$ & $\begin{array}{c}\text { Pico- } \\
\text { phytoplankton } \\
\left(\text { cells } \mathrm{ml}^{-1} \text { ) }\right.\end{array}$ & $\begin{array}{l}\text { Bacteria } \\
\left(\text { cells ml } l^{-1}\right)\end{array}$ & $\begin{array}{c}\text { HNF } \\
\text { (ind. } \mathrm{ml}^{-1} \text { ) }\end{array}$ & $\underset{\left(d^{-1}\right)}{\mu}$ & $\underset{\left(\mathrm{d}^{-1}\right)}{g}$ & $\begin{array}{c}I \\
\text { (bact. } \mathrm{HNF}^{-1} \mathrm{~h}^{-1} \text { ) }\end{array}$ & $\begin{array}{c}C \\
\left(\mathrm{nl} \mathrm{HNF}-1 \mathrm{~h}^{-1}\right)\end{array}$ \\
\hline T2 (0) & $1.14 \times 10^{5}$ & $6.59 \times 10^{4}$ & $3.07 \times 10^{6}$ & $6.88 \times 10^{4}$ & 0.76 & 1.04 & 1.93 & 0.630 \\
\hline T2 (N) & $2.00 \times 10^{5}$ & $8.35 \times 10^{4}$ & $3.42 \times 10^{6}$ & $1.31 \times 10^{5}$ & 2.04 & 2.29 & 2.49 & 0.728 \\
\hline T4 (0) & $1.34 \times 10^{5}$ & $7.36 \times 10^{4}$ & $3.50 \times 10^{6}$ & $4.87 \times 10^{4}$ & 0.62 & 1.01 & 3.02 & 0.863 \\
\hline $\mathrm{T} 4(\mathrm{~N})$ & $2.06 \times 10^{5}$ & $8.99 \times 10^{4}$ & $7.29 \times 10^{6}$ & $1.32 \times 10^{5}$ & 2.00 & 2.27 & 5.20 & 0.714 \\
\hline T9 (0) & $9.53 \times 10^{4}$ & $3.71 \times 10^{4}$ & $6.83 \times 10^{6}$ & $1.39 \times 10^{5}$ & 0.63 & 0.45 & 0.92 & 0.135 \\
\hline T9 (N) & $1.13 \times 10^{5}$ & $7.32 \times 10^{4}$ & $2.54 \times 10^{7}$ & $9.65 \times 10^{5}$ & 0.99 & 0.74 & 0.81 & 0.032 \\
\hline
\end{tabular}




\section{Dynamics of bacterial and HNF communities}

Compared to the moderate increase observed in control mesocosms (0), there was a large change in bacterial abundances when nutrients (N) were added (Fig. 3). Bacterial abundance gradually increased to reach maximal values of $2.54 \times 10^{7}$ cells $\mathrm{ml}^{-1}$ after $9 \mathrm{~d}$ of experiment. Then, they decreased to their initial abundance level at the end of the experiment. The ratio between the tritiated thymidine incorporation and the total number of bacterial cells gives an estimate of the mean specific activity of bacterial cells during the experiment (Fig. 3). No variation in specific activity was observed during the experiment in the control duplicates (0). Two periods of increased specific activity were observed in the enriched mesocosms; the first increase was at the beginning of the experiment, with a maximum value on Day $6(13.4 \times$ $10^{-20} \mathrm{~mol} \mathrm{cell}^{-1} \mathrm{~h}^{-1}$ ). Then, after a weak decrease, there was a second very large increase, with a maximum on Day $12\left(34.5 \times 10^{-20} \mathrm{~mol} \mathrm{cell}^{-1} \mathrm{~h}^{-1}\right)$. HNF counts showed a weak increase in the control mesocosms (0) during the experiment (from $5.2 \times 10^{4}$ to $1.6 \times 10^{5}$ cells ml ${ }^{-1}$ ). In the enriched mesocosms $(\mathrm{N})$, a limited increase was observed during the first $2 \mathrm{~d}$ of the experiment (Fig. 4). However, after Day 6, HNF densities sharply increased, reaching a maximum of abundance $\left(1.1 \times 10^{6} \mathrm{cells} \mathrm{ml}^{-1}\right)$ $10 \mathrm{~d}$ after the beginning of the experiment (Fig. 4). The initial ratio between bacterial and HNF counts was $73 \pm$ 13 (mean \pm SD). During the experiments the ratio exhibited large changes (Fig. 4), especially in the enriched mesocosm (between 11 and 168). These changes were similar in all treatments until Day 8; first, there was a drastic decrease for $2 \mathrm{~d}$, followed by an obvious increase until Day 6, after which a drastic decrease took place again. Then, the ratio increased more or less regularly in the control mesocosms (0), while it decreased further to a minimal value (11) in the enriched mesocosms (N). This

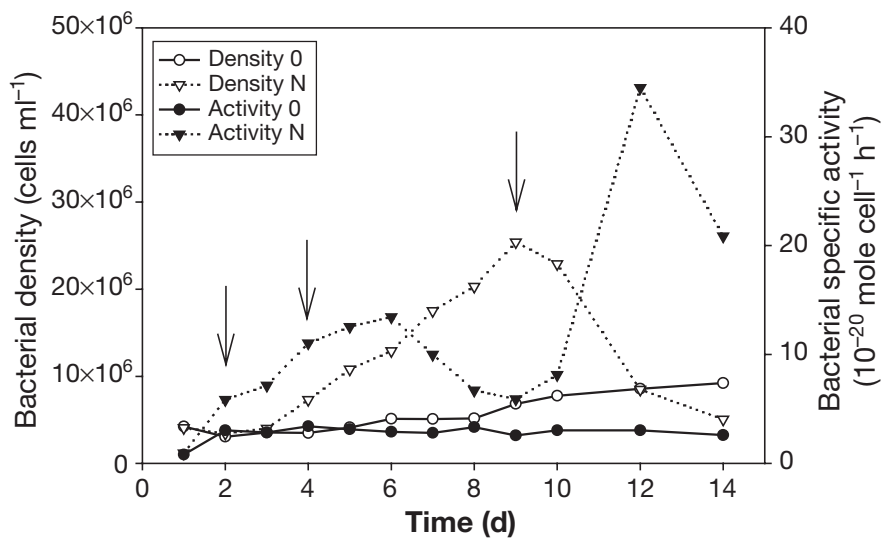

Fig. 3. Changes in the bacterial abundance (cells $\mathrm{ml}^{-1}$ ) and specific activity $\left(10^{-20} \mathrm{~mol} \mathrm{cell}{ }^{-1} \mathrm{~h}^{-1}\right)$ in the control (0) and enriched (N) mesocosms

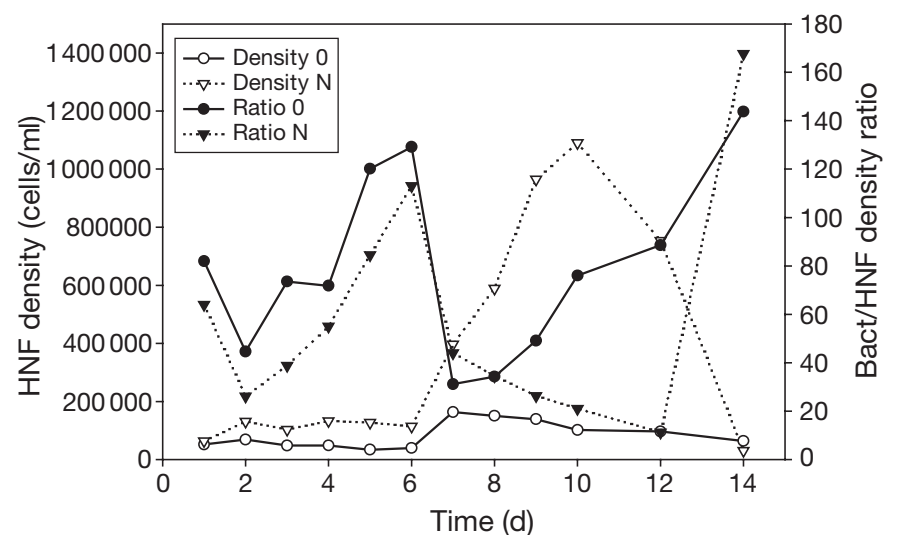

Fig. 4. Changes in the heterotrophic nanoflagellate (HNF) abundance (cells $\mathrm{ml}^{-1}$ ) and ratio between bacterial and HNF abundances in the control (0) and enriched (N) mesocosms

very low ratio in N mesocosms was obtained on Day 12, just after the peak in HNF abundance.

Growth and grazing rates of bacteria

The growth rate of bacteria and grazing rate of protozoans on bacteria, as estimated from dilution experiments, are reported in Table 2. The experiments were performed for the control (0) and nutrient-enriched (N) mesocosms at times T2 (after $2 \mathrm{~d}$ ), T4 (after $4 \mathrm{~d}$ ) and T9 (after $9 \mathrm{~d}$ ). The 3 sampled times corresponded to the lag, the early growth and the final growth phases of the bacterial dynamics. Most of the dilution experiments did not show large changes in apparent $\mu$ values for the low dilution ratios. This may be due to the low ratio between bacterial and HNF abundances, i.e. the grazing pressure of HNF on bacteria has only been significantly reduced for the highest dilutions. In these cases we adjusted the linear regression model only for apparent $\mu$-values that showed a linear relationship with dilution ratios. Growth rates remained stable in the control mesocosms (0), with values ranging between 0.62 and $0.76 \mathrm{~d}^{-1}$ (Table 2). In the enriched mesocosms $(\mathrm{N})$, higher net growth rates were estimated, ranging between 0.99 and $2.04 \mathrm{~d}^{-1}$ at T9 and T2, respectively. There was a close correspondence between growth- and grazing-rate values. Low growth-rate values observed in the control or at the beginning of treatments were associated with low grazing-rate values. Higher net growth- and grazingrate values were observed in the $\mathrm{N}$ treatment, especially at T2 and T4. Ingestion rates of bacteria by HNF showed their highest values on Day 4, in both types of mesocosms (Table 2). Typically, HNF ingest between 3 and 5 bacteria $h^{-1}$, and can filter between 0.73 and $0.86 \mathrm{nl} \mathrm{HNF}{ }^{-1} \mathrm{~h}^{-1}$. 


\section{Size-class structure of bacterial communities}

Size-class structure of bacterial communities was estimated from flow cytometry (FCM) data. Five distinct bacterial populations were discriminated on the basis of their scatter and fluorescence values. Mean side-scatter values of these different populations are reported in Table 3. The existence of these quite different flow cytometric size classes was confirmed by epifluorescence microscopy (Fig. 5), which showed the presence of a large diversity of bacterial cell sizes.

The abundance and the apparent biomass of the different FCM populations in control (0) and enriched (N) mesocosms are illustrated in Fig. 6. Increase of bacterial abundance in the enriched mesocosms $(\mathrm{N})$ was a consequence of the growth of the smaller cells (bact-A population). The largest cells showed (bact-E population) only a limited change in numbers and were always a small fraction of the total abundance $(<1 \%)$. However, despite their low numbers, the largest cells showed the largest apparent biomass at the beginning of the experiment. When nutrient addition was low (0 mesocosms), large cells also formed the highest biomass during most of the experiment. In enriched mesocosms $(\mathrm{N})$, while the largest cells (bact-E population) formed the highest biomass during the first days of the experiment (up to Day 4), the smaller or intermediate sized cells became the dominant population in terms of biomass from Day 8 on (Fig. 6).

\section{Culturable bacteria}

Culturable counts on Marine Agar (colony-forming units, CFU) performed for both treatments showed that the proportion of culturable cells remained low in the control (0), while there was a very large increase of the proportion of these cells in the enriched mesocosm $(\mathrm{N})$ (Fig. 7). This percentage reached nearly $25 \%$ of the total count on Day 14. Unfortunately, we were not able to perform culturable counts between Days 8 and 14, and it may be that a higher value was obtained during this period. The maximum proportion of CFU was not obtained when total counts were the highest on Day 6

Table 3. Side-scatter characteristics of the different bacterial populations discriminated by flow cytometry. Raw values were divided by the side scatter of $0.96 \mu \mathrm{m}$ beads that were added to each sample

\begin{tabular}{|lccccc|}
\hline & A & B & C & D & E \\
\hline Mean & 0.024 & 0.110 & 0.275 & 0.650 & 5.346 \\
SD & 0.005 & 0.029 & 0.041 & 0.105 & 1.122 \\
CV (\%) & 23 & 27 & 15 & 16 & 21 \\
\hline
\end{tabular}

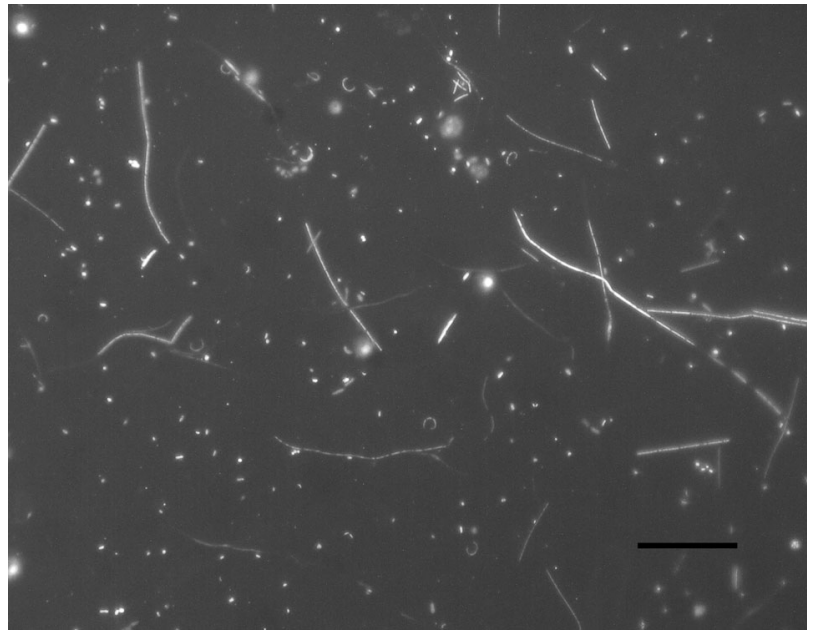

Fig. 5. Photomicrographs by epifluorescence microscopy of a DAPI-stained sample from the enriched mesocosm at T6. Note the presence of (1) both very small and large bacterial cells, (2) vibrioid-shaped cells and (3) flagellates. Scale bar $=10 \mu \mathrm{m}$

(see Fig. 3), but during the decline phase linked to the grazing impact of HNF. This period also corresponded to an important phase of bacterial specific activity, with the highest values recorded on Days 12 and 14. From the Marine Agar plates, 10 strains were isolated during the experiment and then sequenced. The phylogenetic position of these strains (SEN-1 to -10) is reported in Fig. 8. The strains were distributed into 2 clear groups: 6 strains belonged to the Vibrio cluster, and 4 strains, to the Cytophaga-Flavobacteria-Bacteriodes (CFB) cluster. Among the Vibrio cluster, 4 (SEN-1, -3, -6 and -7) of the 6 strains were closely related to $V$. natriegens, 1 (SEN-2) was close to the $V$. natriegens/vulnificus group and the last (SEN-5) was related to a more diverse Vibrio sp. group. The 4 CFB-related strains are included in a cluster that contains 3 different genera (Cytophaga, Tenacibaculum, Flexibacter).

\section{DISCUSSION}

The abundances and activities of different microorganisms recorded in Senegal estuarine waters, e.g. picophytoplankton, heterotrophic flagellates and bacteria, represented some of the highest values published for temperate or tropical coastal systems (Troussellier et al. 2004).

Enrichment experiments in mesocosms have shown that, at least for the time period considered, nitrogen, phosphorus or both limited the growth of bacterial communities. A bacterial growth phase was clearly observed in enriched mesocosms, compared to non- 

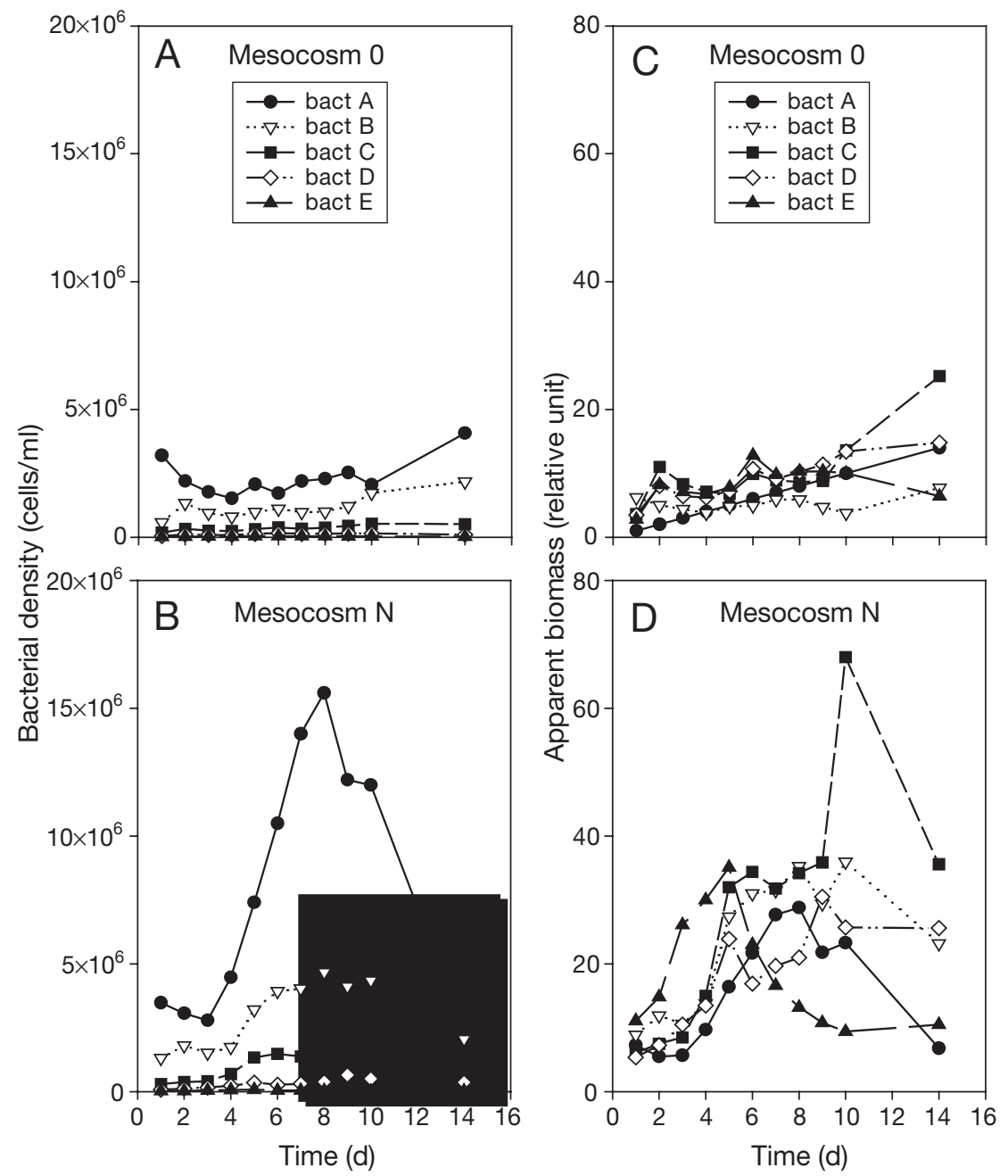

the mesocosms provided the prerequisites for successful use of the dilution method. Ingestion and clearance rates per HNF were among the lowest values to be reported from different marine and freshwater environments (e.g. Carlough \& Meyer 1991, Sanders et al. 1992). The minimum ingestion rate of only 0.81 bacteria $\mathrm{HNF}^{-1} \mathrm{~h}^{-1}$ established on Day 9 corresponded with the maximum HNF abundance (close to $10^{6}$ ind. $\mathrm{ml}^{-1}$ ), and higher ingestion rates were observed during the bacterial growth phase on Day 4. Sanders et al. (2000) reported abundances of HNF typically ranging from ca. $10^{2}$ to $10^{4}$ cells $\mathrm{ml}^{-1}$, in both marine and freshwater planktonic communities, but occasionally exceeding $10^{5} \mathrm{ml}^{-1}$ in extremely eutrophic waters and on marine snow particles. The ratio of bacterium to flagellate abundances was one of the lowest (11 to 251) recorded in the literature (Sanders et al. 1992, Gasol et al. 1995), and confirms that the grazing process is a major factor in controlling the bacterial standing stock in these estuarine waters (top-down control). Despite the high grazing rates, the ingestion rates on bacteria by HNF were low, suggesting that HNF can ingest other picoplanktonic organisms. To explore this hypothesis, the carbon demand of the HNF community has been estimated using the 'apparent growth rate of HNF' (in the presence of their predators)

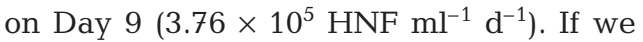
assume an average cell volume of $3.32 \mu^{3}$ for the HNF community ( $n=83$ ), a biovol-

development in the control mesocosms. However, the bacterial growth phase occurred after phytoplankton growth. Thus, it may be that bacteria were not only limited by inorganic nutrients, but also by organic carbon, which may originate from phytoplankton (bottom-up control). This colimitation has already been demonstrated in many reservoirs characterized by low in situ nutrient concentrations (e.g. Carlsson \& Caron 2001, Bouvy et al. 2004).

Simultaneous to the increase of the bacterial growth rate due to nutrient enrichment, grazing-rate values also increased, which provided the first evidence for the close coupling of bacterial and HNF dynamics in this estuary. While the dilution method has been criticized, especially in connection with grazing-rate estimates (Vaqué et al. 1994, Dolan et al. 2000), we think that the high HNF:bacterium ratios observed in

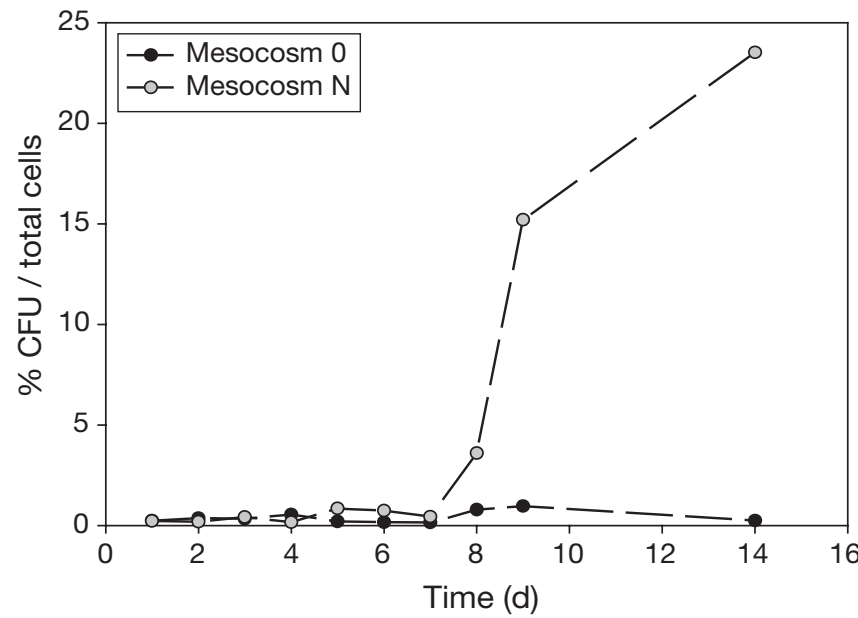

Fig. 7. Changes in proportion of culturable bacterial cells in the control (0) and enriched $(\mathrm{N})$ mesocosms 


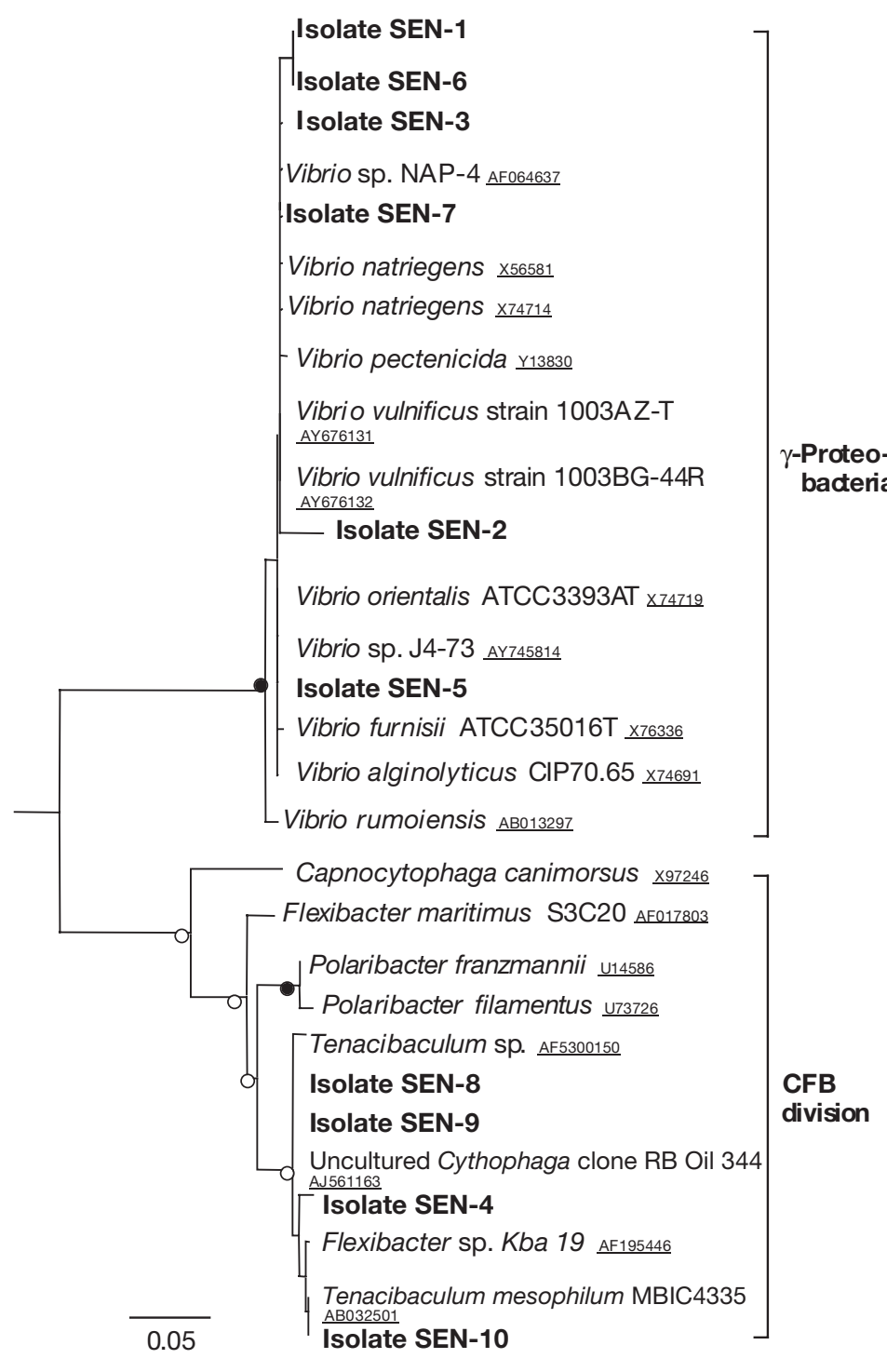

Fig. 8. Phylogenetic tree based on 16S rRNA gene sequences for bacterial strains (isolates SEN-1 to -10) isolated from the enriched mesocosm. Percentages of 100 bootstrap resampling that supported the branching orders in each analysis are shown above or near the relevant nodes (•, values $>85 \%$; O, values $<85 \%$ ). The tree was rooted and outgrouped by using the 16S rRNA sequences of Methanococcus jannaschii (M59126). Evolutionary distance is indicated by vertical lines; each scale bar length corresponds to 0.05 fixed point mutations per sequence position (CytophagaFlavobacteria-Bacteriodes)

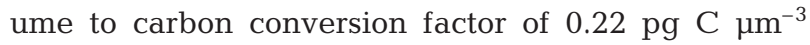
(Borsheim \& Bratbak 1987) and a gross growth efficiency of $30 \%$ (Sherr \& Sherr 1984), HNF community

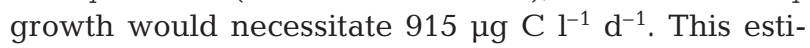
mate is certainly a minimum carbon demand of the HNF community, due to the probable underestimation of their growth rate. Knowing that HNF ingested 19.44 bact. $\mathrm{HNF}^{-1} \mathrm{~d}^{-1}$ (see Table 2, Day 9), total inges- tion of bacterial carbon would only be $419 \mu \mathrm{g} \mathrm{Cl}^{-1}$ $\mathrm{d}^{-1}$, assuming an average bacterial cell volume of $0.099 \mu^{3}(n=554)$ and a biovolume to carbon conversion factor of $0.2 \mathrm{pg} \mathrm{C} \mathrm{\mu m}^{-3}$ (Simon \& Azam 1989). Thus, the ingestion rates of bacteria by HNF would only represent a fraction $(<45.8 \%)$ of the total carbon demand of the HNF community. Another approach can be applied to verify this conclusion, using values based on the tritiated thymidine incorporation rate. If we apply a conversion factor of $1.50 \times 10^{18} \mathrm{cells} \mathrm{mol}^{-1}$ to convert the rates of thymidine incorporation into the bacterial biomass production from the dilution growth experiment (data not shown), the same average bacterial cell volume and the same biovolume to carbon conversion factor (see above), the daily average bacterial production can be estimated at $561 \mu \mathrm{g} \mathrm{C}^{-1} \mathrm{~d}^{-1}$, corresponding to only $61.3 \%$ of the carbon demand of HNF on Day 9. Thus, these 2 independent approaches demonstrated that bacteria satisfied only ca. 50 to $60 \%$ of the HNF carbon demand during their growth phase. Consequently, the HNF community must ingest another type of prey to satisfy their carbon demand. In a previous paper, Troussellier et al. (2004) showed that the phytoplankton community of the Senegal River estuary is characterized by a dominance of pico-sized cells. Their abundances, enumerated by FCM (close to $10^{5}$ cells $\mathrm{ml}^{-1}$ ), appeared to be among the highest reported in the literature (Maggazu \& Decembrini 1995, Vaquer et al. 1996). The high proportion of picophytoplankton in the Senegal River estuary was indicative of a primary producer community adapted to low nutrient concentrations. In the present experiment we also showed that picophytoplanktonic cells were very abundant $\left(3.7\right.$ to $9.0 \times 10^{4}$ cells $\mathrm{ml}^{-1}$ ). They could also constitute edible prey for the HNF community, considering that most pelagic HNF are omnivores feeding on different trophic levels (Boenigk \& Arndt 2002).

The hypothesis that the HNF community relies on the existence of 2 types of prey may also be supported by the size-class distribution of the HNF community (Fig. 9). On Day 9, there were 2 distinct populations of HNF: a population of small organisms characterized by a mean volume of $1.45 \mu^{3}$ (min. $=0.95, \max .=2.07, \mathrm{SD}=0.33$ ) and a population of larger organisms characterized by a mean volume of $3.63 \mu \mathrm{m}^{3}$ (min. $\left.=2.15, \max .=5.68, \mathrm{SD}=0.86\right)$. These 2 distinct populations, both characterized by a normal distribution (Kolmogorov-Smirnof test), might be explained by differences in species composition and/or as the result of the dividing process. Whatever the reason, and in accordance with other studies (e.g. 
Samuelsson \& Andersson 2003, Vaqué et al. 2004), we suggest that the smallest HNF $(<2 \mu \mathrm{m})$ were the main consumers of bacteria and that the medium and largest size classes can use picophytoplanktonic cells as prey to satisfy their carbon requirements.

As a consequence of the high HNF grazing pressure, the structure of bacterial assemblages exhibited different features. In the grazing phase, we observed an increase in the mean specific activity of bacterial cells and an increase in the proportion of culturable cells. The maximum specific activity values (30 to $35 \times$ $10^{-20} \mathrm{~mol} \mathrm{cell}^{-1} \mathrm{~h}^{-1}$ ) estimated in the enriched mesocosms were among the highest reported in the literature (Troussellier et al. 2004). Solic \& Krstulovic (1994) also observed a higher thymidine incorporation per bacterial cell in the presence of predators. In fact, the high grazing pressure exerted by HNF may both stimulate bacterial growth by supplying dissolved organic matter through excretion (Taylor et al. 1985) and select for the bacterial populations with the highest growth rates. Therefore, high grazing pressure on bacteria was followed by high bacterial growth, enhancing turnover of bacterial biomass. The high proportion of culturable cells was also amongst the highest percentages recorded in marine coastal waters. High percentages of culturable cells seemed only to occur in enriched environments (Fukami et al. 1985, Lebaron et al. 2001). This may be the consequence of (1) the selection of culturable species and/or (2) the selection of active cells versus dormant or less active cells, the last of these being grazed and disappearing at least for a given time from the community.

The limited number of sequenced culturable strains isolated from Senegal estuarine waters does not, of

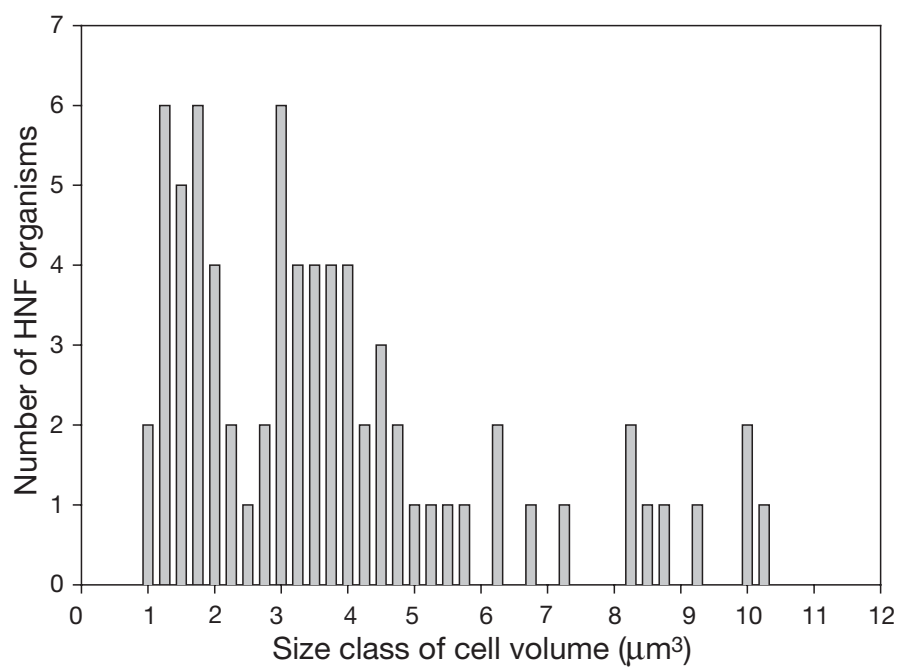

Fig. 9. Size-class distribution of cell volume of heterotrophic nanoflagellate (HNF) communities on Day 9 during the dilution method course, allow us to analyze the composition of the culturable bacterial community, but it does allow us to identify at least 2 kinds of species with different potential strategies for resisting grazing pressure. Strains related to the Vibrio genus, and especially to Vibrio natriegens, can be considered bacteria with a very fast growth potential (Eagon 1962). This property, combined with the relatively small size of these cells, may allow these strains to escape grazing pressure. The selection of bacterial populations with a high divisionrate strategy under flagellate predation has already been demonstrated in experimental systems (Pernthaler et al. 1997). Strains of the CFB cluster may use another resistance strategy to grazing. Flexibacter species are known to form large filaments (Hahn et al. 1999), which could protect these bacteria from flagellate grazing. This grazing resistance mechanism has already been reported, but not in a systematic way (Posch et al. 1999), and mainly in activated sludge plant or eutrophic freshwater ecosystems (Wagner et al. 1994, Sommaruga \& Psenner 1995, Hahn et al. 1999, Jürgens et al. 1999, Langenheder \& Jürgens 2001). The presence of elongated cells in marine environments is only observed in controlled experiments in coastal waters (Shiah \& Ducklow 1995, Havskum \& Hansen 1997, Troussellier et al. 1999), and not in oligotrophic waters (Jürgens et al. 2000).

We can hypothesize that the dominance of 1 of the 2 kinds of grazing-resistant bacterial populations may be driven by the nutrient level of the system. To be able to have high division rates Vibrio natriegens-like bacteria must have a non-limited nutrient environment. Filamentous CFB-like bacterial populations, once they reach a size at which they are no longer edible, do not require high growth and division rates. In coastal waters one may expect that nutrient concentrations will be heterogeneous, both in space and time, according to different causes (nutrient inputs, proportion of aggregates, nutrient regeneration processes, etc.). Thus, Vibrio-like populations exhibit large and quick changes in numbers, while CFB-like populations show slower, but more persistent, dynamics. This hypothesis was supported by the dynamics of bacterial populations detected by flow cytometry. First, a large diversity in the different size classes (5 classes) was observed. It was also noted that, when no nutrients were added, the largest cells (such as Flexibacter spp.) formed the highest proportion of bacterial community biomass. Adding nutrients, stimulated the growth of smaller cells (such as V. natriegens), which then often formed the dominant biomass. As concluded by Gasol et al. (2002), it is evident that sufficient nutrients must be available for protozoans to cause changes in the composition of the bacterial community.

The results of this study added to the concept that predation is an important force in shaping the struc- 
ture and function of the bacterial community (e.g. Jürgens \& Matz 2002). However, our results suggest that bacterial communities were not the only prey HNF used to satisfy their carbon requirements during their growth phase. In fact, the HNF community exerts a high grazing pressure on all picoplankton microorganisms, including picophytoplankton, which were present in large numbers in this ecosystem due to their ability to use low concentrations of inorganic nutrients, as is the case in the Senegal estuary. It may be that the HNF community is characterized by 2 distinct populations (in terms of size class according to cell volume) and, in a more general way, that heterotrophic flagellates can use both heterotrophic bacteria and picophytoplankton or switch between the 2 types of prey, which would explain the large abundances of HNF populations observed in the Senegal River estuary. However, it is difficult to establish the details of predator pressure on bacteria due solely to flagellates when larger protists are also present. Indeed ciliates can also be important bacterivores, as has been reported for estuarine environments by Vaqué et al. (1992). Further experiments will be needed to more precisely determine the impact of ciliates on flagellates and bacteria, and also to identify the feeding pressure on the microbial food web by various mesozooplankton present in the Senegal River estuary.

Acknowledgements. This work was part of a study dedicated to the Senegal River estuary, and supported by the IRD Research unit 'FLAG' 098 (key factors and consequences of algal blooms in shallow systems). The authors are indebted to the 2 reviewers for their constructive comments and criticism. Sincere thanks to Yvan Bettarel for helpful discussions and for improving the English. We wish to thank Dr. Xavier Lazzaro and his team for the conception of mesocosms and their in situ installation.

\section{LITERATURE CITED}

Albaret JJ, Laë R (2003) Impact of fishing on fish assemblages in tropical lagoons: the example of the Ebrie lagoon, West Africa. Aquat Living Resour 16:1-9

Arfi R, Bouvy M, Menard F (2002) Environmental variability at a coastal station near Abidjan (Gulf of Guinea): oceanic and continental influences. In: McGlade JM, Cury $P$, Koranteng KA, Hardman-Mountford NJ (eds) The Gulf of Guinea large marine ecosystem. Elsevier, Amsterdam, p 103-118

Azam F, Fenchel T, Field JG, Gray JS, Meyer-Reil LA, Thingstad F (1983) Ecological role of water column microbes in the sea. Mar Ecol Prog Ser 10:257-263

Blackburn N, Hagström $\AA$, Wikner J, Cuadros-Hansson R, Bjornsen PK (1988) Rapid determination of bacterial abundance, biovolume, morphology, and growth by neural network-based image analysis. Appl Environ Microbiol 64:3246-3255

Boenigk J, Arndt H (2002) Bacterivory by heterotrophic flagellates: community structure and feeding strategies. Antonie Leeuwenhoek 81:465-480
Borsheim KY, Bratbak G (1987) Cell volume to cell carbon conversion factors for a bacterivorous Monas sp. enriched from sea water. Mar Ecol Prog Ser 36:171-175

Bouvy M, Troussellier M, Got P, Arfi R (2004) Bacterioplankton responses to bottom-up and top-down controls in a West African reservoir (Sélingué, Mali). Aquat Microb Ecol 34:301-307

Carlough LA, Meyer JL (1991) Bacterivory by sestonic protists in a southeastern blackwater river. Limnol Oceanogr 36: 873-883

Carlsson P, Caron DA (2001) Seasonal variation of phosphorus limitation of bacterial growth in a small lake. Limnol Oceanogr 46:108-120

Cloern JE (2001) Our evolving conceptual model of the coastal eutrophication problem. Mar Ecol Prog Ser 210:223-253

Costanza R, d'Arge R, de Groot R, Farber S and 9 others (1997) The value of the world's ecosystem services and natural capita. Nature 387:253-260

Davis PG, Sieburth JMcN (1984) Estuarine and oceanic microflagellate predation of actively growing bacteria: estimation by frequency of dividing-divided bacteria. Mar Ecol Prog Ser 19:237-246

Dolan JR, Gallegos LL, Moigis A (2000) Dilution effects on microzooplankton in dilution grazing experiments. Mar Ecol Prog Ser 200:127-139

Ducklow HW, Carlson CA (1992) Oceanic bacterial production. In: Marshall KC (ed) Advances in microbial ecology, Vol 12. Plenum Press, New York, p 113-181

Ducklow HW, Shiah F (1993) Bacterial production in estuaries. In: Ford T (ed) Aquatic microbiology: an ecological approach. Blackwell Scientific, Boston, MA, p 261-287

Eagon RG (1962) Pseudomonas natriegens, a marine bacterium with a generation time of less than 10 minutes. J Bacteriol 83:736-737

Fuhrman JA, Azam F (1980) Bacterioplankton secondary production estimates for coastal waters of British Columbia, Antarctica, and California. Appl Environ Microbiol 39:1085-1095

Fukami K, Simidu U, Taga N (1985) Microbial decomposition of phyto- and zooplankton in seawater. II. Changes in the bacterial community. Mar Ecol Prog Ser 21:7-13

Gasol JM, Simons AM, Kalff J (1995) Patterns in the top-down versus bottom-up regulation of heterotrophic nanoflagellates in temperate lakes. J Plankton Res 17:1879-1903

Gasol JM, Pedros-Alio C, Vaqué D (2002) Regulation of bacterial assemblages in oligotrophic plankton systems: results from experimental and empirical approaches. Anthonie Leeuwenhoek 81:435-452

Hahn M, Moore ER, Höfle M (1999) Bacterial filament formation, a defense mechanism against flagellate grazing, is growth rate controlled in bacteria of different phyla. Appl Environ Microbiol 65:25-35

Havskum H, Hansen AS (1997) Importance of pigmented and colourless nano-sized protists as grazers on nanoplankton in a phosphate-depleted Norwegian fjord and in enclosures. Aquat Microb Ecol 12:139-151

Iriarte A, Madariaga I, Revilla M, Sarobe A (2003) Short-term variability in microbial food web dynamics in a shallow tidal estuary. Aquat Microb Ecol 31:145-161

Jürgens K, Matz C (2002) Predation as a shaping force for the phenotypic and genotypic composition of planktonic bacteria. Antonie Leeuwenhoek 81:413-434

Jürgens K, Pernthaler J, Schalla S, Amann R (1999) Morphological and compositional changes in a planktonic bacterial community in response to enhanced protozoan grazing. Appl Environ Microbiol 65:1241-1250

Jürgens K, Gasol JM, Vaqué D (2000) Bacteria-flagellates 
coupling in microcosm experiments in the central Atlantic Ocean. J Exp Mar Biol Ecol 245:127-147

Kirchman DL (2000) Microbial ecology of the oceans. WileyLiss, New York

Kirchman DL (2002) The ecology of Cytophaga-Flavobacteria in aquatic environments. FEMS Microbiol Ecol 39: 91-100

Kuosa H (1990) Protozoan grazing on pico- and nanophytoplankton in the northern Baltic Sea: direct evidence from epifluorescence microscopy. Arch Hydrobiol 119:257-265

Landry MR, Hassett RP (1982) Estimating the grazing impact of marine micro-zooplankton. Mar Biol 67:283-288

Langenheder S, Jürgens K (2001) Regulation of bacterial biomass and community structure by metazoan and protozoan predation. Limnol Oceanogr 46:121-134

Laybourn-Parry J, Parry J (2000) Flagellates and the microbial loop. In: Leadbeater BSC, Green JC (eds) The flagellates. Taylor \& Francis, London, p 216-239

Lebaron P, Servais P, Troussellier M, Courties C and 7 others (2001) Microbial community dynamics in Mediterranean nutrient-enriched seawater mesocosms: changes in abundances, activity and composition. FEMS Microbiol Ecol 34: 255-266

Maggazu G, Decembrini F (1995) Primary production, biomass and abundance of phototrophic picoplankton in the Mediterranean Sea: a review. Aquat Microb Ecol 9:97-104

Marie D, Partenski F, Jacquet S, Vaulot D (1997) Enumeration and cell cycle analysis of natural populations of marine picoplankton by flow cytometry using the nucleic acid stain SYBER Green I. Appl Environ Microbiol 63:186-193

Murrel MC (2003) Bacterioplankton dynamics in a subtropical estuary: evidence for substrate limitation. Aquat Microb Ecol 32:239-250

Nixon SW (1988) Physical energy inputs and the comparative ecology of lake and marine ecosystems. Limnol Oceanogr 33:1005-1025

Pernthaler J, Posch T, Šimek K, Vrba J, Amann R, Psenner R (1997) Contrasting bacterial strategies to coexist with a flagellate predator in an experimental microbial assemblage. Appl Environ Microbiol 63:596-601

Porter KG, Feig YS (1980) The use of DAPI for identifying and counting aquatic microflora. Limnol Oceanogr 25:943-948

Posch T, Šimek K, Vrba J, Pernthaler J, Nedoma J, Sattler B, Sonntag B, Psenner R (1999) Predator-induced changes of bacterial size-structure and productivity studied on an experimental microbial community. Aquat Microb Ecol 18: 235-246

Robarts RD, Zohary T (1993) Fact or fiction — bacterial growth rates and production as determined by (methyl- $\left.{ }^{3} \mathrm{H}\right)$-thymidine? Adv Microb Ecol 13:371-425

Samuelsson K, Andersson A (2003) Predation limitation in the pelagic microbial food web in an oligotrophic aquatic system. Aquat Microb Ecol 30:239-250

Sanders RW, Caron DA, Berninger UG (1992) Relationships between bacteria and heterotrophic nanoplankton in marine and fresh waters: an inter-ecosystem comparison. Mar Ecol Prog Ser 86:1-14

Sanders RW, Berninger UG, Lim EL, Kemp PF, Caron DA (2000) Heterotrophic and mixotrophic nanoplankton predation on picoplankton in the Sargasso Sea and on Georges Bank. Mar Ecol Prog Ser 192:103-118

Scialabba N (1998) Integrated coastal area management and agriculture, forestry and fisheries. FAO guidelines. Environment and Natural Resources Service, FAO, Rome
Sherr BF, Sherr EB (1984) Role of heterotrophic Protozoa in carbon and energy flow in aquatic ecosystems. In: Klug MJ, Reddy CA (eds) Current perspectives in microbial ecology. American Society for Microbiology, Washington, DC, $\mathrm{p}$ 412-423

Sherr EB, Sherr BF (2002) Significance of predation by protists in aquatic microbial food webs. Antonie Leeuwenhoek 73:239-308

Shiah FK, Ducklow HW (1995) Regulation of bacterial abundance and production by substrate supply and bacterivory: a mesocosm study. Microb Ecol 30:239-255

Simon M, Azam F (1989) Protein content and protein synthesis rates of planktonic marine bacteria. Mar Ecol Prog Ser 51:203-213

Solic M, Krstulovic N (1994) Role of predation in controlling bacterial and heterotrophic nanoflagellate standing stocks in the coastal Adriatic Sea: seasonal patterns. Mar Ecol Prog Ser 114:219-235

Sommaruga R, Psenner R (1995) Permanent presence of grazing-bacteria in a hypertrophic lake. Appl Environ Microbiol 61:3457-3459

Strickland JDH, Parsons TR (1972) A practical handbook of seawater analysis. Bull Fish Res Board Can 167:1-311

Strom SL (2000) Bacterivory: interactions between bacteria and their grazers. In: Kirchman DL (ed) Microbial ecology of the oceans. Wiley-Liss, New York

Taylor GT, Iturriaga R, Sullivan CW (1985) Interactions of bactivorous grazers and heterotrophic bacteria with dissolved organic matter. Mar Ecol Prog Ser 23:129-141

Torréton JP, Guiral D, Arfi R (1989) Bacterioplankton biomass and production during destratification in a monomictic eutrophic bay of a tropical lagoon. Mar Ecol Prog Ser 57:53-67

Troussellier M, Courties C, Vaquer A (1993) Recent applications of flow cytometry in aquatic microbial ecology. Biol Cell 78:111-121

Troussellier M, Courties C, Lebaron P, Servais P (1999) Flow cytometric discrimination of bacterial populations in seawater based on SYTO 13 staining of nucleic acids. FEMS Microbiol Ecol 29:319-330

Troussellier M, Got P, Bouvy M, M'Boup M and 5 others (2004) Water quality and health status of the Senegal River estuary. Mar Pollut Bull 48:852-862

Vaqué D, Pace ML, Findlay SEG, Lints D (1992) Fate of bacterial production in an heterotrophic ecosystem: grazing by protists and metazoans in the Hudson estuary. Mar Ecol Prog Ser 89:155-163

Vaqué D, Gasol JM, Marrasé C (1994) Grazing rates on bacteria: the significance of methodology and ecological factors. Mar Ecol Prog Ser 109:263-274

Vaqué D, Agusti S, Duarte CM (2004) Response of bacterial grazing rates to experimental manipulation of an Antarctic coastal nanoflagellate community. Aquat Microb Ecol 36:41-52

Vaquer A, Troussellier M, Courties C, Bibent B (1996) Standing stock and dynamics of picophytoplankton in the Thau lagoon (northwest Mediterranean coast). Limnol Oceanogr 41:1821-1828

Wagner MR, Amann R, Kämpfer P, Assmus B, Hartmann P, Springer N, Schleifer KH (1994) Identification and in situ detection of gram-negative filamentous bacteria in activated sludge. Syst Appl Microbiol 17:405-417

Yentsch CS, Menzel DW (1963) A method for the determination of phytoplankton chlorophyll and pheophytin by fluorescence. Deep-Sea Res 10:221-231

Submitted: November 19, 2004; Accepted: May 2, 2005

Proofs received from author(s): June 29, 2005 